\title{
Secrecy beyond reason
}

\section{The Reagan Administration continues to apply widely its demand for secrecy in scientific matters that have any bearing on national security. It is time for more vocal opposition.}

CAN only two years have passed since officials of the Reagan Administration were visiting scientific meetings and warning American researchers that academic science was "the soft underbelly" of national security? In 1982, the administration's apparent obsession with the notion that Soviet spies were tricking American scientists into giving away the nation's technological secrets set the government and the universities at loggerheads. In several celebrated cases, the universities (notably and creditably Stanford University in California) refused State Department requests to act as policemen when Soviet and Chinese scholars visited their campuses. To defuse the situation, the National Academy of Sciences published a report, Scientific Communication and National Security, which tried to find a reasonable compromise between the legitimate worries of the defence establishment and the traditional commitment of the United States to free and open communication in science. By 1984, technology transfer - at least insofar as it affects the universities appears to have become the great forgotten issue of US science policy.

A famous victory for the National Academy of Sciences? Hardly. If little is heard about technology transfer, it is not because the Reagan Administration has promptly accepted the recommendations put forward by the academy's report. In a choice irony, the deafening silence from the White House is a product of a decision that the administration's response to the academy's report on scientific communication should itself be kept secret. Dr Frank Press, the academy's president, originally expected an early response from the White House science office. Later, the job was handed from the science office to a senior inter-agency group meeting under the aegis of the National Security Council. Now, the response is believed to be complete but it has been classified as secret.

It would be tempting to believe that there was little cause for concern. After all, most recent cases of government intervention in technology transfer have consisted of efforts to prevent Eastern bloc nations from illegally importing bits of American hardware, such as sophisticated computers. It was always the contention of the universities that technological transfers of that kind - rather than international communication in academic science - were the only really significant examples of hostile countries gaining militarily useful information. The National Academy panel, chaired by Cornell University's former president, Dale Corson, concluded that academic science was a relatively unimportant source of Soviet poaching, and that the dispute between the universities and the administration could be resolved by building tall fences around a very small number of areas of great sensitivity. The universities have been as good as their word; their voluntary agreement to submit papers on cryptography for prepublication screening has, for example, worked remarkably well.

There is however, little reason to suppose that the administration has decided to accept the general philosophy of the Corson report. The available evidence suggests the opposite. Far from agreeing to confine its attention to a small number of highly sensitive technologies, the administration appears to want to extend its control over scientific communication as far as possible. In a little-noticed recent directive, for example, the Department of Defense has begun to insist that all basic and applied contract research it sponsors in universities must be submitted for pre- publication screening. Only if the research cannot be placed within a very loose definition of "sensitivity" can it be submitted for publication without pre-screening.

It is too early to say whether this new policy will result in the suppression of articles that could otherwise be published without compromising national security. One hopeful sign is that the Department of Defense has at last set up an internal appeals board to review borderline decisions. But there are also ominous signs that the department's aggressive attitude towards technology transfer is fostering something akin to a siege mentality in which relatively low-ranking officers are opting for secrecy simply because they want to play safe or, in some cases, because they do not understand the complex rules through which the administration's technology transfer policy is being implemented. Recent meetings on materials science, held at the University of Dayton, Ohio, and the University of California, Los Angeles, have been closed to foreign nationals, including scientists from North Atlantic Treaty Organization (NATO) countries. And last month a meeting of the American Ceramics Society in Cocoa Beach, Florida, was split into two halves with one, technically no longer a meeting of the society, being sponsored separately by the Department of Defense and the National Aeronautical and Space Administration and restricted to US citizens.

The prevalence of secrecy in government departments which sponsor scientific research is bad enough. What is worse is the apparent unwillingness of academic scientists to kick up a fuss when unwarranted restrictions are placed on publications and meetings. In 1982, it was the readiness of scientists to insist on the importance of open scientific communication that prompted the National Academy to produce the Corson report. Now that the report appears to have vanished without trace, the need for vigilance is all the greater.

\section{Time to back Europe}

\section{When research ministers meet in Brussels next}

\section{week, they should back the Commision.}

THE French launched the idea of " a European 'space' for science and technology" in their all-but forgotten memorandum to the Athens summit last December. In Toulouse a couple of weeks ago, socialists from the European Parliament backed the same idea. The meeting was unfocused and hence ineffectual, but at least it indicated concern: Europe is certainly not a "space for science", but a polyglot and divided continent where scientific mobility is almost non-existent.

Something must be done! The cry has echoed around the laboratories of Europe for years - but now there is a new determination to find structures that will work, to avoid institutional atrophy and tired bureaucracy. The goal is real, flexible, European collaboration in science and technology.

Even that temple of bureaucracy and powerhouse of paper in Brussels - the European Commission, the executive arm of the European Economic Community (EEC) - is fired with the new zeal. It burns brightest in the person of research and industry commissioner (and vice-president) Etienne Davignon, a Belgian tipped for the presidency next year, and in his director-general for research, Italian biologist Professor Paolo Fasella. With the aid 